\title{
Bizarre Leiomyoma
}

National Cancer Institute

\section{Source}

National Cancer Institute. Bizarre Leiomyoma. NCI Thesaurus. Code C4257.

A morphologic variant of leiomyoma characterized by the presence of pleomorphic muscle cells with bizarre hyperchromatic nuclei and eosinophilic cytoplasm. 